\title{
Performance Evaluation of Locally-Produced Waste Cooking Oil Biodiesel with Conventional Diesel Fuel
}

\author{
Abid Ali Khaskheli \\ Department of Mechanical Engineering, \\ Quaid-e-Awam University of Engineering, Science and \\ Technology, Nawabshah, Pakistan \\ abidali_lifeskill@yahoo.com
}

Abdul Sattar Jamali

Department of Mechanical Engineering,

Quaid-e-Awam University of Engineering, Science and

Technology, Nawabshah, Pakistan

jamali_sattar@yahoo.com

\section{Zafar Ali Siyal}

Department of Energy and Environment Engineering, Quaid-e-Awam University of Engineering, Science and Technology, Nawabshah, Pakistan zafarsiyal@yahoo.com

\author{
Gordhan Das Walasai \\ Department of Mechanical Engineering, \\ Quaid-e-Awam University of Engineering, Science and \\ Technology, Nawabshah, Pakistan \\ valasai@quest.edu.pk \\ Qadir Bakhsh Jamali \\ Department of Mechanical Engineering, \\ Quaid-e-Awam University of Engineering, Science and \\ Technology, Nawabshah, Pakistan \\ qadirquest@gmail.com \\ Abdullah Mengal \\ Department of Mechanical Engineering, \\ Balochistan University of Engineering and Technology, \\ Khuzdar, Pakistan \\ ahmengal@yahoo.com
}

\begin{abstract}
Increasing environmental concerns forced us to look for cheaper, reliable and secure sources of energy. Fossil fuels like oil, coal, and natural gas are having limited supplies and are depleting fast. Both energy security and environmental concerns have resulted in inclination towards renewable energy sources. Biodiesel does not contain petroleum, but it can be blended with petro-diesel in various mix levels. This research investigated biodiesel produced by the use of cheap waste cooking oil, collected from the local market of Nawabshah, Pakistan. The collected waste oil was converted into biodiesel by transesterification process at PCSIR Laboratory, Karachi. The fuel samples were tested in a diesel engine test bed unit at the Thermodynamics Laboratory of Quaid-e-Awam University. Biodiesel blends were compared with the conventional diesel fuel. The comparative analysis of the performance parameters concluded that brake specific fuel consumption of B30 (biodiesel $30 \%+$ diesel $70 \%$ ) mix was $6.9 \%$ higher than that of $100 \%$ diesel. The brake thermal efficiency of $\mathrm{B30}$ decreased about $4.75 \%$ in comparison with conventional diesel.
\end{abstract}

Keywords-biodiesel; WCO; BSFC; BTE; engine

\section{INTRODUCTION}

Biodiesel can be produced with the use of waste cooking oil (WCO) as raw material. Four types of WCO, sunflower, maize, olive and palm can be used for the production of biodiesel [1]. Global petroleum production is decreased while the current reserves are limited [2]. B100 is generally known as fresh fiery alternate fuel and can be produced from domestic and renewable resources. It comprises no petroleum and can be blended by any ratio level with petroleum diesel to produce biodiesel blends. Biodiesel is produced by the use of methanol and ethanol with alkali catalyst. Biodiesel blends can be used with conventional diesel with or without any major modification. WCO biodiesel has less ignition delay. The blend of $20 \%$ WCO biodiesel $+80 \%$ diesel has good brake thermal efficiency and indicates slightly more specific fuel consumption [3]. It is used as an environmentally friendly fuel. It has decreased greenhouse gas emissions and particulate matter emissions and other air toxics. Biodiesel reduces premature exhausting of fuel pumps and recovers lubricity [4].

\section{RELATED STUDIES}

WCO biodiesel is renewable, biodegradable and nontoxic. Physical parameters like methyl ester fatty acids which are produced by the esterification process are similar to those of diesel. Blended biodiesel can be used in engines directly without any modification. Other feed stocks have also been used in the synthesis of biodiesel [5-7]. The EU prefers raw materials such as rapeseed oil, sunflower oil and cotton-seed oil $[8,9]$. The production of biodiesel from waste vegetable oil is cheaper than from other feed stocks. The benefits of using WCO to produce biodiesel are its low cost and the decreased emitted greenhouse gasses [10]. The density of WCO is about $10 \%$ greater and the kinematic viscosity of WCO is 10 times greater than that of conventional diesel. Some modifications are compulsory in the engine when WCO is used in engines [9, 
11]. If the free fatty acids (FFAs) of WCO oil are greater than $2 \%$ then it needs esterification process before transesterifcation [12].

\section{EXPERIMENTAL SETUP}

WCO was collected from two different chicken frying shops in Nawabshah. It was converted in biodiesel by transesterification on PCSIR Laboratory at Karachi, by the algorithm shown in Figure 1.

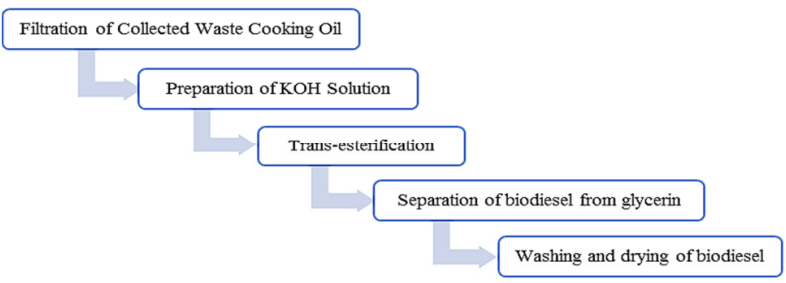

Fig. 1. Algorithm for bio-diesel production

Filter/cotton cloth filtered the collected WCO. The oil to methanol ratio was $1: 8$. $183 \mathrm{ml}$ of methanol were put in a beaker of $250 \mathrm{ml}$, along with $13.5 \mathrm{~g}$ of dissolved $\mathrm{KOH}$. $500 \mathrm{~g}$ of WCO were taken in a glass flask connected with a reflux condenser using tap water to condense methanol vapour. The mixture was agitated by the use of a magnetic stirrer, and heated to $55^{\circ} \mathrm{C}-60^{\circ} \mathrm{C}$. When oil temperature increased to $55^{\circ} \mathrm{C}$ $60^{\circ} \mathrm{C}$, the prepared $\mathrm{KOH}$ solution was poured into the oil with stirring at $150 \mathrm{rpm}$. After one hour, the mixture was poured into a separating funnel. Glycerol, additional methanol and unused products were in the lower layer and were separated. The upper layer of biodiesel (ester) was washed several times with warm water $\left(40^{\circ} \mathrm{C}\right)$ until the washing was neutral. The final product (biodiesel) was then dried over anhydrous sodium sulphate and filtered.

\section{PERformance EVAluation}

Diesel performance evaluation was carried out in the Thermodynamics Laboratory of the Quaid-e-Awam University of Engineering, Science and Technology Nawabshah, Sindh, Pakistan. The engine model was DWE-6/10-JS-DV. The specification details of the engine are illustrated in Table I.

TABLE I. DIESEL TEST ENGINE SPECIFICATIONS

\begin{tabular}{|c|c|}
\hline Number of cylinders & 1 \\
\hline Cooling system & Water cooled \\
\hline Type & Horizontal \\
\hline Piston size (bore) & $80 \mathrm{~mm}$ \\
\hline Displacement of piston (strokes) & $95 \mathrm{~mm}(477 \mathrm{cc})$ \\
\hline Compression ratio & $23: 1$ \\
\hline Starting method & Manual \\
\hline Output/rotational speed & $8.5 \mathrm{PS} / 2200 \mathrm{rpm}(\max )$ \\
\hline
\end{tabular}

Two fuel tanks were attached to the diesel engine test bed. One common pipeline was used for supplying fuel to the engine. Both fuel tanks were linked with the common line. The flow could be controlled by two separate valves as shown in Figure 2. The first tank was filled with diesel fuel (D100), and the second one with the test selected fuel. Under this study, three selected fuels were tested: Diesel (D100), 20\% biodiesel $+80 \%$ diesel (B20) and 30\% biodiesel $+70 \%$ diesel (B30). Their specifics are given in Table III. Exhaust gas temperature (EGT), brake specific fuel consumption (BSFC) and brake thermal efficiency (BTE) were measured at constant engine speed and variable load ranged from $0 \mathrm{~kg}$ to $2.0 \mathrm{~kg}$ at $1300 \mathrm{rpm}$.

TABLE II. FUEL COMPOSITION BY VOLUME

\begin{tabular}{|c|c|}
\hline D100 & Pure Diesel \\
\hline B100 & $100 \%$ Biodiesel \\
\hline B20 & $20 \%$ biodiesel $+80 \%$ diesel \\
\hline B30 & $30 \%$ biodiesel $+70 \%$ diesel \\
\hline
\end{tabular}

TABLE III. COMPARATIVE PHYSICAL PROPERTIES OF OIL SAMPLES

\begin{tabular}{|c|c|c|c|c|c|c|}
\hline $\begin{array}{c}\text { Physical } \\
\text { Property }\end{array}$ & Unit & D100 & B20 & B30 & $\begin{array}{c}\text { ASTM } \\
\text { standard }\end{array}$ & $\begin{array}{c}\text { Testing } \\
\text { limits }\end{array}$ \\
\hline $\begin{array}{c}\text { Total Acid } \\
\text { Number }\end{array}$ & $\mathrm{mgKOH} / \mathrm{g}$ & 0.24 & 0.27 & 0.28 & $\mathrm{D}-664$ & $0.80 \mathrm{max}$ \\
\hline $\begin{array}{c}\text { Specific } \\
\text { gravity* }\end{array}$ & - & 0.83 & 0.85 & 0.84 & $\mathrm{D}-891$ & $0.8-0.9$ \\
\hline $\begin{array}{c}\text { Kinematic } \\
\text { Viscosity** }\end{array}$ & $\mathrm{mm}^{2} / \mathrm{s}$ & 1.98 & 2.78 & 2.43 & $\mathrm{D}-445$ & $1.9-6.0$ \\
\hline Density*** & $\mathrm{g} / \mathrm{cm}^{3}$ & 0.85 & 0.86 & 0.86 & $\mathrm{D}-1298$ & $0.86-0.90$ \\
\hline $\begin{array}{c}\text { Cetane index } \\
\text { (Calculated) }\end{array}$ & - & 56.9 & 54.4 & 53.5 & $\mathrm{D}-976$ & 47 min \\
\hline Flash point & ${ }^{0} \mathrm{C}$ & 103 & 123 & 115 & $\mathrm{D}-93$ & $130 \mathrm{~min}$ \\
\hline Pour Point & ${ }^{0} \mathrm{C}$ & 0 & +1.5 & +1.8 & $\mathrm{D}-97$ & -15 to +5 \\
\hline $\begin{array}{c}\text { Calorific } \\
\text { value }\end{array}$ & $\mathrm{MJ} / \mathrm{kg}$ & 44.8 & 43.2 & 43.8 & $\mathrm{D}-240$ & $37.5-45$ \\
\hline
\end{tabular}

Fig. 2. Experimental setup of diesel engine

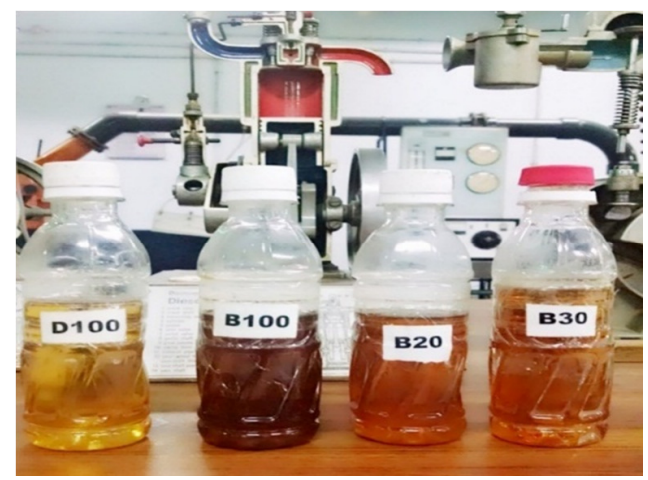

Fig. 3. D100 and biodiesel specimens 


\section{RESULTS AND DISCUSSION}

Performance analysis was determined on a single cylinder diesel engine. A dynamometer was directly joined to the engine and could control the varying load. A dynamometer controller was connected to the panel. A water tank for cooling, and two fuel tanks were attached to the diesel engine test bed. One common pipeline has been used to supply the fuel. Three different fuel types were experimented with. The performance parameters were determined on varying load at $1300 \mathrm{rpm}$. The load range was 0 N.m-2N.m. In this comparative study, the performance parameters were EGT, BSFC and BTE with varying brake power (BP).

\section{A. Exhaust Gas Temperature (EGT)}

EGT increases continuously with load increase. During high engine load considerable heat was rejected. Biodiesel and its blends have decreased percentage of heat rejected by the cooling fluid due to their lower combustion temperature. The smaller burning gas temperature is responsible for biodiesels' quick combustion for the period of premixed combustion. It was observed that at increasing brake load the engine using D100 exhausted more temperature than when using B20 and $\mathrm{B} 30$, whereas B30 had reduced exhaust temperature than B20. The comparative results of EGT are shown in Figure 4.

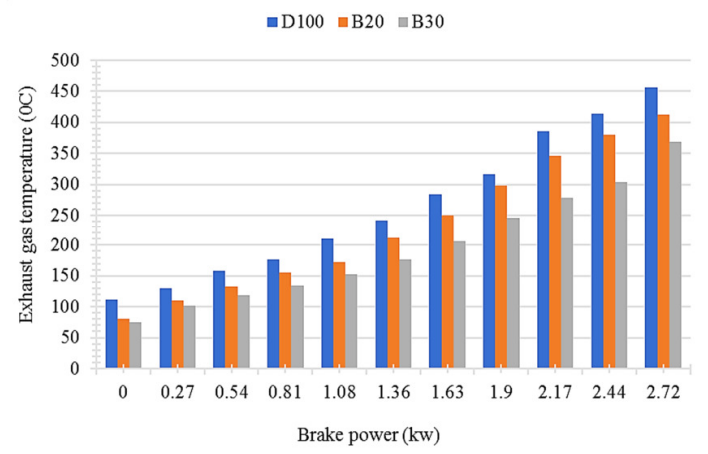

Fig. 4. Comparative results of EGT with BP

\section{B. Brake Specific Fuel Consumption (BSFC)}

Biodiesel showed higher BSFC than diesel for each different brake power of the engine because biodiesel and its blends have lower density and calorific value. The SPFC has been expressed by $\mathrm{kg} / \mathrm{kWh}$. BSFC increases at high loads having improved fuel smoke related with the high fuel-air mixture in the compression-ignition (CI) engine. At low loads BSFC increases due to decreased mechanical efficiency. It is observed that brake fuel consumption is increased with increase in the blending ratio of biodiesel due to biodiesel's low viscosity and density. Consequently, the BSFC of B30 was higher than the ones of D100 and B20. The BSFC of B30 was $6.9 \%$ higher than that of D100 and $2.9 \%$ than that of B20. The detailed of comparative results of BSFC are shown in Figure 5.

\section{Brake Thermal Efficiency (BTE)}

The BTE decreased when the blending ratio increased. The compression ratios of the blended biodiesel were compared with pure diesel D100. The air-fuel ratio and volumetric efficiency decreased with increase in the concentration of biodiesel in the fuel [13-15]. It was observed that vegetable oil blends with methanol and ethanol provide lower thermal efficiency than diesel fuel. The BTE of diesel is higher than that of biodiesel fuel due its higher viscosity, lower heating value, poor spray quality and higher volatility $[16,17]$. Increase in blending percentage of biodiesel in the diesel fuel improves its combustion process due to biodiesel's higher oxygen content. The average value of BTE of B30 is decreased by $4.75 \%$ when compared to D100. The comparative results of BTE are shown in Figure 6.

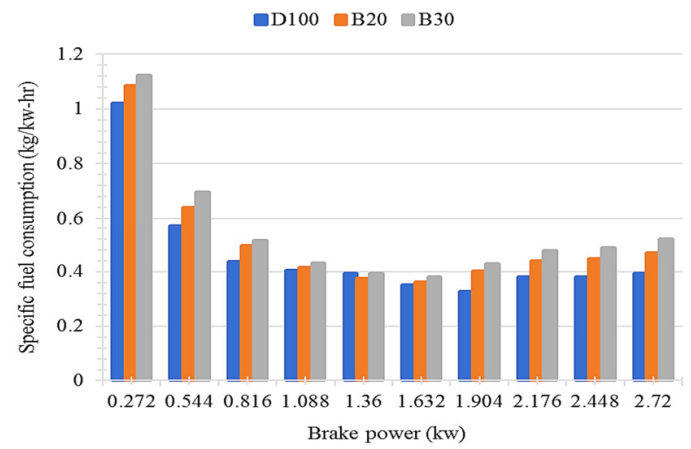

Fig. 5. Comparative results of BSFC with BP

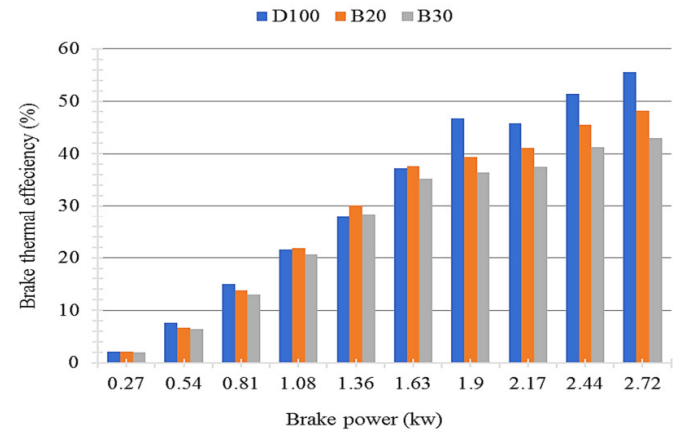

Fig. 6. Comparative results of BTE with BP

\section{CONCLUSION}

This research and experimental work consisted in engine performance analysis. Three fuels, D100, B20 and B30 were tested without any modification of the diesel engine. Based on the obtained results, B30 showed reduced exhaust gas temperature due to its quick combustion and improved fuel characteristics. The BSFC of B30 was $6.9 \%$ higher than the one of D100 due to its higher combustion and large oxygen content. BTE was lower for biodiesel as compared to D100. When the blending percentage of biodiesel in the diesel fuel increased, the average value of BTE of B30 decreases $4.75 \%$ as compared to D100.

\section{REFERENCES}

[1] V. Cordero-Ravelo, J. Schallenberg-Rodriguez, "Biodiesel production as a solution to waste cooking oil (WCO) disposal. Will any type of WCO do for a transesterification process? A quality assessment", Journal of Environmental Management, Vol. 228, pp. 117-129, 2018 
[2] M. Abe, S. Hirata, H. Komatsu, K. Yamagiwa, H. Tajima, "Thermodynamic selection of effective additives to improve the cloud point of biodiesel fuels", Fuel Vol. 171, pp. 94-100, 2016

[3] Y. H. Teoh, H. H. Masjuki, M. A. Kalam, M. A. Amalina, H. G. How, "Impact of waste cooking oil biodiesel on performance, exhaust emission and combustion characteristics in a light-duty diesel engine", SAE Technical Paper 2013-01-2679, 2013

[4] A. M. A. Attia, A. E. Hassaneen, "Influence of diesel fuel blended with biodiesel produced from waster cooking oil on diesel engine performance", Fuel Vol. 167, pp. 316-328, 2016

[5] A. E. Atabani, A. S. Silitonga, H. C. Ong, T. M. I. Mahlia, H. H Masjuki, I. A. Badruddin, H. Fayaz, "Non-edible vegetable oils a critical evaluation of oil extraction, fatty acid compositions, biodiesel production, characteristics and engine performance and emissions production", Renewable and Sustainable Energy Reviews, Vol. 18, pp. 211-245, 2013

[6] S. H. Dhawane, T. Kumar, G. Halder, "Biodiesel synthesis from Hevea brasiliensis oil employing carbon supported heterogeneous catalyst: optimization by Taguchi method", Renewable Energy, Vol. 89, pp. 506514,2016

[7] S. H. Dhawane, A. P. Bora, T. Kumar, G. Halder, "Parametric optimization of biodiesel synthesis from rubber seed oil using iron doped carbon catalyst by Taguchi approach", Renewable Energy, Vol. 105, pp. 616-624, 2017

[8] A. Bokhari, L. F. Chuah, S. Yusup, J. J. klemes, R. N. M. Kamil, "Optimisation on pretreatment of rubber seed (Hevea brasiliensis) oil via esterification reaction in a hydrodynamic cavitation reactor", Bioresource Technology, Vol. 199, pp. 414-422, 2016

[9] N. H. Abdullah, S. H. Hasan, N. R. M. Yusoff, "Biodiesel Production Based on Waste Cooking Oil (WCO)", Internationals Journal of Materials Science and Engineering, Vol. 1, No. 2, pp. 94-99, 2013

[10] M. Mofijur, A. E. Atabani, H. H. Masjuki, M. A. Kalam, B. M. Masum, "A study on the effects of promising edible and non-edible biodiesel feedstocks on engine performance and emissions production: A comparative evaluation", Renewable and Sustainable Energy Reviews, Vol. 23, pp. 391-404, 2013

[11] A. E. Atabani, A. S. Silitonga, I. A. Badruddin, T. M. I. Mahlia, H. H. Masjuki, S. Mekhilef, "A comprehensive review on biodiesel as an alternative energy resource and its characteristics", Renewable and Sustainable Energy Reviews, Vol. 16, No. 4, pp. 2070-2093, 2012

[12] E. M. Shahid, Y. Jamal, A. N. Shah, N. Rumzan, M. Munsha, "Effect of Used Cooking Oil Methyl Ester on Compression Ignition Engine", Journal of Quality and Technology Management, Vol. 8, pp. 91-104, 2012

[13] V. G. Gude, G. E. Grant, "Biodiesel from waste cooking oils via direct sonication", Applied Energy, Vol. 109, pp. 135-144, 2013

[14] S. Photaworn, C. Tongurai, S. Kungsanunt, "Process development of two-step esterification plus catalyst solution recycling on waste vegetable oil possessing high free fatty acid", Chemical Engineering and Processing: Process Intensification, Vol. 118, pp. 1-8, 2017

[15] S. Nandi, "Performance of C.I Engine by Using Biodiesel-Mahua Oil", American Journal of Engineering Research, Vol. 2, No. 1, pp. 22-47, 2013

[16] M. Vijay Kumar, A. Veeresh Babu, P. Ravi Kumar, "The impacts on combustion, performance and emissions of biodiesel by using additives in direct injection diesel engine", Alexandria Engineering Journal, Vol. 57, pp. 509-516, 2018

[17] N. H. Abu-Hamdeh, K. A. Alnefaie, "A Comparative Study of Almond Biodiesel-Diesel Blends for Diesel Engine in Terms of Performance and Emissions, BioMed Research International, Vol. 2015, Article ID 529808, 2015 